\title{
Assessing the Recreational Value of a National Forest Park from Ecotourists' Perspective in Taiwan
}

\author{
Wan-Yu Liu ${ }^{1}$ (D) Pin-Zheng Chen ${ }^{2}$ and Chi-Ming Hsieh ${ }^{3, *}$ \\ 1 Department of Forestry, National Chung Hsing University, Taichung City 40227, Taiwan \\ 2 Innovation and Development Center of Sustainable Agriculture, National Chung Hsing University, \\ Taichung City 40227, Taiwan \\ 3 International Bachelor Program of Agribusiness, National Chung Hsing University, \\ Taichung City 40227, Taiwan \\ * Correspondence: hsiehch9@nchu.edu.tw; Tel.: +886-4-2284-0849 (ext. 622)
}

Received: 15 June 2019; Accepted: 23 July 2019; Published: 29 July 2019

\begin{abstract}
The Huisun National Forest Recreation Area (HNFRA), which preserves over $85 \%$ of the forest to its natural state, provides many forest services, including environmental exploration, ecological conservation, recreation, and ecotourism in Taiwan. This study used analytical methods to analyze the recreational demands that influence tourists' visits and the recreational value of tourism. The travel cost method (TCM) and the zero-truncated negative binomial regression model to assess the recreational value were chosen. The results revealed that the travel costs for nonlocal visitors were higher than those for local visitors by NT\$818.59. The recreational demand was negatively correlated to income and had a significantly positive correlation with place of residence, age, and length of stay. The estimated annual recreational value of HNFRA was NT\$3237 per person, and the total annual recreational value was NT\$347,270,560. Raising the idea that recreational demand and the willingness to consume has a direct impact on the recreational value. Enhancing the site's recreational value will be beneficial to ecotourists' experiences and the management of HNFRA.
\end{abstract}

Keywords: recreational value; forest ecosystem service; travel cost method; zero-truncated negative binomial regression

\section{Introduction}

As reported by Directorate General of Budget, Accounting and Statistics, Executive Yuan, Taiwan (2017) [1], the average national income per capita in Taiwan has remarkably increased in the last 10 years. In addition, citizens' travel demands increased since the "five-workday a week" policy was implemented in 2001. Visiting forests has gradually become a pertinent part of life and it relieves work-related pressure [2]. According to statistics by the Tourism Bureau, Ministry of Transport and Communications (MOTC), Taiwan (2017) [3], the average number of domestic trips each year increased from 5.57 to 9.04 times a person during 2007 to 2016. Moreover, the most commonly reported tourist activity (62\% of tourists) is visiting forests [3]. Therefore, forest recreation is the most important recreational activity in Taiwan.

The Huisun National Forest Recreation Area (HNFRA) in Nantou County, Taiwan is selected as the research site. It covers 7747 hectares and is one of the experimental forests managed by the Experimental Forest Management Office of National Chung Hsing University (NCHU). The HNFRA has been established since the early 20th century and $85 \%$ of its forests are still preserved in mostly natural state. Due to a large altitude difference in this area, temperatures and scenery vary accordingly, resulting in a wide range of flora and fauna as well as the preservation of rare species. For instance, the Taiwan blue magpie is endemic to Taiwan, and is a rare and valuable protected bird species. The 
Cycad-fern and Lindera aggregata are plants that rarely exist in the other areas in Taiwan; most of them appear only in the HNFRA. Especially, cycad-fern is a plant species distributed rarely in Taiwan. Visitors can enjoy the natural scenery and various leisure activities, such as forest bathing, picnicking, and hiking [4]. A lot of tourists are attracted to HNFRA every year. Figure 1 shows the number of tourists from 2007 to 2016, according to the statistics provided by the Tourism Bureau, MOTC, Taiwan (2017) [3]. Overall, the number of tourists increased over time with a peak in 2015 with 204,384 tourists. The number of tourists declined in some years due to severe natural disasters such as typhoons.

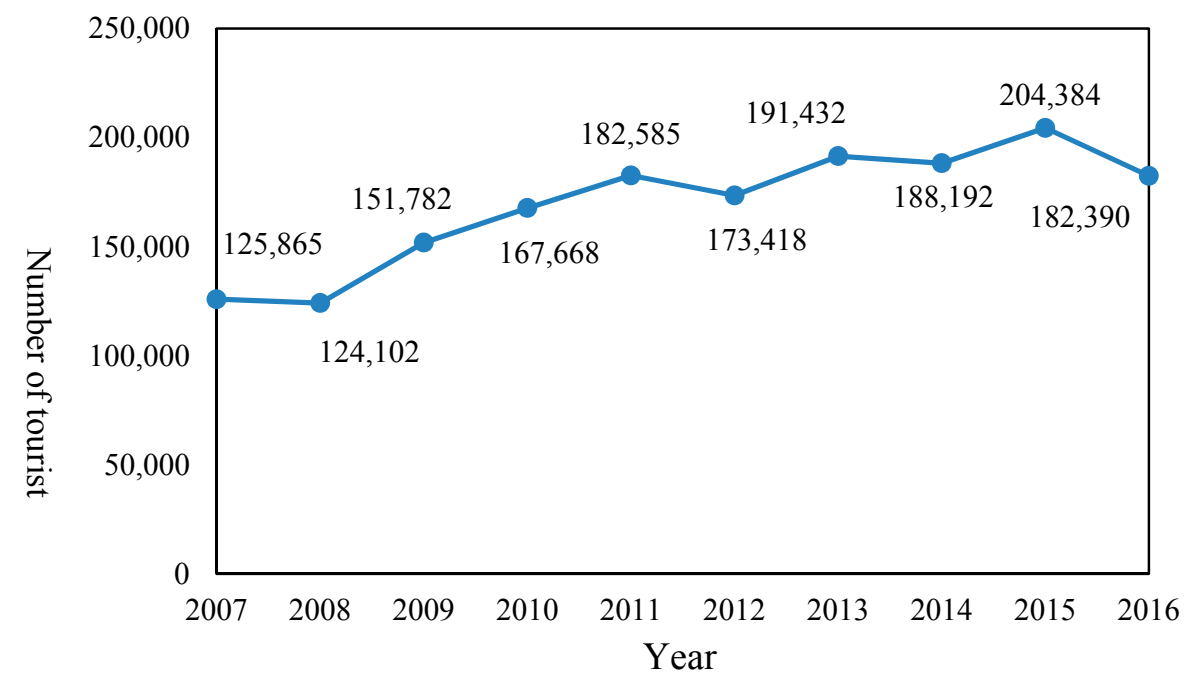

Figure 1. Number of tourists to Huisun National Forest Recreation Area (HNFRA) from 2008 to 2017.

When promoting the HNFRA, it is necessary to understand its recreational value, which serves as a pertinent reference for relevant management and as a benchmark for assessing economic value. However, the current research of recreational values and tourism in the HNFRA is lacking, and needs to be quantified and assessed.

Therefore, this study used the travel cost method (TCM) to evaluate the value of nonmarket goods, because the TCM is effective and commonly used for evaluating the recreational value and policies related to planning recreational activities [5]. Numerous studies have used the TCM to analyze recreational value. Studies on national parks include Liao (2006) and Rathnayake (2016) [6,7]; those on forest recreational areas include Chen (1998) and Zhang (2016) [2,8].

The objectives of this study include: 1) Evaluating the recreational value of HNFRA through the TCM; 2) estimating the annual recreational value per capita (NTD: Note that USD $1=$ NTD 30.565 in August, 2018.) and the total recreational value (NTD) of the HNFRA combined with different statistical analyses; 3 ) exploring the differences and correlations between the characteristics of visitors' socioeconomic backgrounds and their recreational behaviors, along with their demands and travel costs; and 4) classifying visitors into two categories (local visitors and nonlocal visitors) based on the distance between their places of residence and the HNFRA. The results of this study can provide a reference for the future management of the HNFRA.

\section{Materials and Methods}

\subsection{Travel Cost Method}

The basic concept of the TCM is that round-trip travel costs of a recreational site associate to the value of the site linked with visitors' willingness to spend time for travelling to the area [8]. It is used in the research of empirical models to understand the relationship between recreational demands and travel costs [9]. 
Two TCM approaches are used: the zonal travel cost method (ZTCM) and the individual travel cost method (ITCM) [10]. In ZTCM, the recreational site is separated into several areas according to the distance of visitors' place of residence and each area is considered as a unit. A data model can be obtained given information about the relationship between visitors' travel costs and their travel rates. We can then use the average travel cost to identify the total recreational demands and to evaluate the recreational value of the specific area. The assumption of the ZTCM is that tourists from the same area have the same travel preferences, travel costs, and tourist income levels, which are used for travels with a single destination. This implies that a closer area associates to a larger tourist count and a higher tourist rate [11]. However, under normal conditions, each tourist in a given area features different travel costs, travelling methods, and multiple destinations, thus making the ZTCM inaccurate. In contrast, ITCM uses individual tourists as research objects and considers each person's travel expenses and other socioeconomic characteristics $[12,13]$. The demand function of the relationship between visitors' travel costs and their recreational demands is used to evaluate the recreational value of a given recreational area. The ITCM is considered more appropriate than the ZTCM [14]. An ITCM analysis also suits sites with many tourists because it uses a more detailed survey of visitors [15-17]. Therefore, this study selected the ITCM as the research method for evaluating the recreational value of HNFRA.

\subsection{Recreational Value}

In this study, recreational value was evaluated using the Poisson regression model [18]. However, the Poisson regression model asks for nonnegative integer input values and the variance has to be equal to the mean before it can be statistically analyzed [18-20]. Yet, under normal circumstances, the mean is not equal to the standard deviation, and in most cases the variance is greater than the mean. A negative binomial regression model can be used to establish the demand function [14] because negative binomial regression models allow the variance to be greater than the mean [21]. The negative binomial regression formula is given as follows:

$$
E(y \mid x)=\exp (\beta \cdot \chi)=\exp \left(\beta_{0}+\beta_{1} \chi_{1}+\beta_{2} \chi_{2}+\cdots \beta_{i} \chi_{i}\right)
$$

where $\beta \mathrm{i}$ is a negative binomial regression coefficient, and $\beta 0$ is a constant. Since this study was conducted through onsite questionnaire survey, zero number of visits is not an option for the respondents as their recreational demand value. This is known as truncated data, and the problem of truncation leads to bias in the estimation of the model [14]. Therefore, this study used the zero-truncated negative binomial regression (ZTNB) for recreational demand. The ZTNB can be used to solve the analysis error caused by truncation [22-24].

\subsection{Variable Selection and Calculation}

The variables affecting recreational demand have five dimensions: travel costs, socioeconomic background, environmental quality, recreational behaviors, and substitute site variable [14].

\subsubsection{Travel Costs}

In this study, travel costs including accommodation cost (A), transportation cost (MTC), time cost (TTC), and consumer expense (OE) [14] were considered. The details of these four costs are elaborated as follows:

- Accommodation cost is the total amount per capita for accommodation expenses in HRFRA.

- Transportation cost is the cost of back-and-forth transportation. It can be further divided into four modes of transportation: public transportation, tour buses, bicycles or walking, and automobiles or scooters. Using open-ended questions, we inquired about public transportation costs and costs of tour buses by asking the tourists how much they spent. The transportation fee for walking or cycling is nil. As for automobiles and scooters, the cost depends on fuel consumption. The calculation is as follows: This study assumed that the automobiles considered were normal 
passenger cars travelling at a fixed average speed of $60 \mathrm{~km} / \mathrm{h}$, whereas scooters travel at an average speed of $40 \mathrm{~km} / \mathrm{h} \mathrm{[14]}$. The length of their journey (time) and fuel consumption are also taken into consideration.

- For time cost, numerous studies $[6,25,26]$ have focused on the time spent travelling to recreational areas and the time spent inside such areas. If recreational demands are used as dependent variables, the TTC should not include the stay time within a recreational site because it would result in a biased estimation. Moreover, the length of stay is at the visitors' discretion; thus, it should be set as an endogenous variable. However, the travel time to a recreational site is affected by the distance, making it an exogenous variable. Therefore, it is not appropriate to combine the two factors because the endogenous variable could generate endogeneity $[6,25,26]$. Therefore, this study only considers the travel time for a round trip to HNFRA without including the time of stay.

- Consumer expense includes souvenirs bought, food, drinks, and admission fee in HNFRA [14]. The admission fee can be found from the HNFRA's official website (HNFRA, 2017).

\subsubsection{Socioeconomic Background and Recreational Behavior}

The demographic features that this study examined were gender (GENDER), age (AGE), living area (AREA), level of education (EDU), personal monthly income (INC), length of stay (LOS), transportation time (TRATIME), and number of passengers (NIP).

\subsubsection{Environmental Quality}

A measurement method used by Zhang et al. (2015) [14], which has a maximum of 10 points and a minimum of 1 point, was adopted in this study. The recognition of a high environmental quality indicates that the service quality visitors obtained in the recreational area was also relatively high. This can serve as a follow-up reference for managers for environmental protection [27].

\subsubsection{Substitute Sites}

This study used binary variables $(0,1)$ as representative values, where 1 indicates an intentional visit to HNFRA and 0 indicates a fortuitous visit. Assuming that there are similar recreational sites near HNFRA, there is a high substitutability between the two sites, which may cause the recreational value to be underestimated compared with the actual value [28].

In accordance with the travel characteristics and demands introduced in this study, all the required variables are shown in Table 1.

Table 1. Definitions of the variables used in the present study.

\begin{tabular}{|c|c|c|}
\hline Type & Variable (code) & Explanation \\
\hline \multirow{5}{*}{$\begin{array}{l}\text { Socioeconomic } \\
\text { variables }\end{array}$} & Gender (GENDER) & Dummy variable $($ Male $=1$, Female $=0$ ) \\
\hline & Age (AGE) & Continuous variable (years) \\
\hline & Personal income (INC) & Continuous variable (NT\$) \\
\hline & Level of education (EDU) & $\begin{array}{l}\text { Dummy variable } \\
\text { (Elementary school = } 1 \text {; junior high school = 2; high } \\
\text { school/vocational school = } 3 \text {; university/college for } \\
\text { professional training = } 4 \text {; Master's degree or above = 5) }\end{array}$ \\
\hline & Living area (AREA) & Dummy variable (local = 1 ; nonlocal $=0$ ) \\
\hline \multirow{4}{*}{ Travel costs } & $\mathrm{A}+\mathrm{MTC}$ & Transportation costs + accommodation (NT\$) \\
\hline & $\mathrm{A}+\mathrm{TTC}+\mathrm{MTC}$ & $\begin{array}{l}\text { Transportation costs + accommodation + time } \\
\text { costs (NT\$) }\end{array}$ \\
\hline & $\mathrm{A}+\mathrm{OE}+\mathrm{MTC}$ & $\begin{array}{l}\text { Transportation costs }+ \text { accommodation }+ \text { consumer } \\
\text { expenses (NT\$) }\end{array}$ \\
\hline & $\mathrm{A}+\mathrm{OE}+\mathrm{TTC}+\mathrm{MTC}$ & $\begin{array}{l}\text { Transportation costs }+ \text { accommodation }+ \text { time costs }+ \\
\text { consumer expenses (NT\$) }\end{array}$ \\
\hline
\end{tabular}


Table 1. Cont.

\begin{tabular}{lll}
\hline Type & Variable (code) & Explanation \\
\hline $\begin{array}{l}\text { Environmental } \\
\text { quality }\end{array}$ & SAT & $\begin{array}{l}\text { Continuous variable (points), visitors' evaluation of the } \\
\text { local environment (minimum 1 point, maximum } \\
10 \text { points) }\end{array}$ \\
\hline $\begin{array}{l}\text { Recreational } \\
\text { behavior }\end{array}$ & Length of stay (LOS) & Continuous variable (h) \\
\cline { 2 - 3 } & Transportation time (TRATIME) & Continuous variable (h) \\
\cline { 2 - 3 } Substitute sites & Number of companions (NIP) & Continuous variable (people) \\
\hline
\end{tabular}

Sources: Zhang et al. (2015) [14] and the present study. Note: "A" represents the accommodation costs (NT\$),

"MTC" the transportation costs (NT\$), "TTC" the time cost (NT\$), and "OE" the consumer expenditure (NT\$).

\subsection{Questionnaire Design}

The subjects were selected using a convenience sampling method [29]. The questionnaire was divided into four parts: visitors' demographics, visitors' consumer behavior, visitors' recreational behavior, and visitors' perception of their recreational experience. The visitors' demographics part included gender, age, level of education, place of residence, and monthly income. Only visitors aged over 18 years were selected to complete the questionnaire because people under this age generally lack financial means. The visitors' consumer behavior part included the individual expenses, such as admission fee, parking fee, dining fees, and money spent on souvenirs and accommodation. The visitors' recreational behavior part included the number of visits to HNFRA over the last year, the average number of visits to HNFRA on a yearly basis, the transportation time (one way), the means of transport used by the visitors, the length of stay, the total number of passengers, and whether it was an intentional or fortuitous trip. The number of visits to HNFRA in the past year was the recreational demand, which was used as an independent variable in the consumer demand function [14]. Both the transportation time and the means of transport indicated visitors' transportation costs and time costs. The length of stay, the number of people whom each visitor travelled with, and the substitute sites indirectly affected the visitors' recreational demands $[2,14,29]$. The perception of recreational experience part is associated to visitors' feelings about HNFRA. It included leisure activities that the visitors like to engage in, an estimation of the degree of the visitors' willingness to revisit, and of their recognition of the environmental quality of the site. For each item, the highest score was 10 points, 5 points was a medium score, and 1 point represented the lowest score. The survey was conducted in August and September 2017, covering both weekdays and holidays. We went to the HNFRA to distribute questionnaires in person. The questionnaires were distributed in the most visited scenic and recreational areas. A total of 250 questionnaires were distributed, and 223 valid questionnaires were received (This study adopted the following sampling formula to estimate the number of sample questionnaires to be distributed: $n=\frac{Z^{2} * p(1-p)}{e^{2}}$, where $\mathrm{n}$ is the sample size; $\mathrm{Z}$ is the $\mathrm{Z}$-score under a certain confidence level; $\mathrm{p}$ is the ratio of samples, and is assumed to 0.5 ; e is the margin of error. This study assumed that under a $95 \%$ confidence level, the z-score is 1.96; and the margin of error e is $7 \%$. Therefore, the total number of effective samples should be no less than 196.).

\section{Results}

A reliability analysis of the valid questionnaires was conducted. The Cronbach's $\alpha$ coefficient value of the three dimensions was 0.852 , indicating that the content of the questionnaires was reliable and had internal consistency. 


\subsection{Descriptive Statistics}

The visitors' attributes are shown in Tables 2 and 3. A majority of the visitors (57\%) were women. The majority of visitors were aged 50-64 years, accounting for $38.6 \%$ of the total, with an average age of 44.31 years. As for the age of the local visitors, the majority were aged 18-29 years, accounting for $33.6 \%$ of the local visitors, with an average age of 40.25 . As for the age of the nonlocal visitors, the majority were aged 50-64 years, accounting for $49.5 \%$ of nonlocal visitors, with an average age of 49.75. Regarding the level of education, visitors with a degree from a university or a college accounted for $56.5 \%$ of the total. As for the level of education of local and nonlocal visitors, most of the surveyed people had a degree from a university or a college. Regarding monthly income, the majority earned between NT $\$ 20,000$ and NT $\$ 40,000$ a month, accounting for $29.6 \%$ of the total (the average monthly salary was NT\$2,690.58). As for the respondents' career status, the majority worked in the service industry, accounting for $17.5 \%$ of the total, followed by people employed in the army, public sectors, and teachers, accounting for $15.7 \%$ of the total. Retired people and students also represented a considerable part of the total with all accounting for $12.6 \%$ of the total. The majority $(57.4 \%)$ of the visitors were local tourists.

Table 2. Quantitative analysis of the visitors.

\begin{tabular}{|c|c|c|c|c|c|c|}
\hline \multirow[b]{2}{*}{ Variable } & \multicolumn{2}{|c|}{$\begin{array}{l}\text { Overall Visitors } \\
(n=223)\end{array}$} & \multicolumn{2}{|c|}{$\begin{array}{l}\text { Local Visitors } \\
(n=128)\end{array}$} & \multicolumn{2}{|c|}{$\begin{array}{l}\text { Nonlocal Visitors } \\
(n=95)\end{array}$} \\
\hline & Mean & $\begin{array}{l}\text { Standard } \\
\text { Deviation }\end{array}$ & Mean & $\begin{array}{l}\text { Standard } \\
\text { Deviation }\end{array}$ & Mean & $\begin{array}{l}\text { Standard } \\
\text { Deviation }\end{array}$ \\
\hline Age & 44.31 & 14.08 & 40.25 & 14.16 & 49.76 & 12.02 \\
\hline Gender $^{1}$ & 0.43 & 0.49 & 0.46 & 0.50 & 0.39 & 0.49 \\
\hline Level of education $^{2}$ & 3.87 & 0.74 & 3.88 & 0.71 & 3.84 & 0.76 \\
\hline Monthly income (NT\$) & $42,690.58$ & $21,870.39$ & $40,468.75$ & $20,345.81$ & $45,684.21$ & $23,549.00$ \\
\hline Place of residence ${ }^{3}$ & 0.57 & 0.50 & - & - & - & - \\
\hline $\begin{array}{l}\text { Recreational demand (number } \\
\text { of visits/per year) }\end{array}$ & 1.71 & 1.10 & 2.05 & 1.24 & 1.25 & 0.65 \\
\hline Substitute sites ${ }^{4}$ & 0.91 & 0.29 & 0.90 & 0.30 & 0.92 & 0.28 \\
\hline Company (number of people) & 20.43 & 38.10 & 10.90 & 13.99 & 33.28 & 53.38 \\
\hline Length of stay (h) & 16.49 & 18.97 & 16.86 & 22.48 & 15.99 & 12.91 \\
\hline Travelling time (h) & 2.28 & 1.15 & 1.73 & 0.76 & 3.01 & 1.17 \\
\hline Environmental rating ${ }^{5}$ (points) & 7.44 & 1.58 & 7.27 & 1.72 & 7.67 & 1.36 \\
\hline \multicolumn{7}{|c|}{$\begin{array}{l}\text { Source: Compiled by this study. Note: } \operatorname{Gender}^{1}(\text { Male }=1 \text {, female }=0) \text {; level of education }{ }^{2}(\text { elementary school }=1 \text {, } \\
\text { junior high school }=2 \text {, high school/vocational school }=3 \text {, university } / \text { college for professional training }=4 \text {, Master's } \\
\text { degree or higher }=5 \text { ); living } \text { area }^{3}(\text { local visitors }=1 \text {, nonlocal visitors }=0) \text {, substitute sites }{ }^{4} \text { (intentional visit }=1 \text {, } \\
\text { fortuitous visit }=0 \text { ); environmental rating }{ }^{5} \text { (minimum } 1 \text { point, maximum } 10 \text { points). The gray color represents the } \\
\text { highest value. }\end{array}$} \\
\hline
\end{tabular}

Table 3. Frequency statistical analysis of visitors' demographics.

\begin{tabular}{|c|c|c|c|c|c|c|c|}
\hline \multirow{2}{*}{ Variable } & & \multicolumn{2}{|c|}{$\begin{array}{l}\text { Overall Visitors } \\
(n=223)\end{array}$} & \multicolumn{2}{|c|}{$\begin{array}{l}\text { Local Visitors } \\
(n=128)\end{array}$} & \multicolumn{2}{|c|}{$\begin{array}{l}\text { Nonlocal Visitors } \\
(n=95)\end{array}$} \\
\hline & & Number & $\begin{array}{l}\text { Percentage } \\
(\%)\end{array}$ & Number & $\begin{array}{l}\text { Percentage } \\
(\%)\end{array}$ & Number & $\begin{array}{l}\text { Percentage } \\
(\%)\end{array}$ \\
\hline \multirow{2}{*}{ Gender } & $\mathrm{M}$ & 96 & 43.0 & 59 & 46.1 & 37 & 38.9 \\
\hline & $\mathrm{F}$ & 127 & 57.0 & 69 & 53.9 & 58 & 61.1 \\
\hline \multirow{4}{*}{ Age } & 18-29 years & 51 & 22.9 & 43 & 33.6 & 8 & 8.4 \\
\hline & 30-49 years & 71 & 31.8 & 32 & 32.8 & 29 & 30.5 \\
\hline & 50-64 years & 86 & 38.6 & 39 & 30.5 & 47 & 49.5 \\
\hline & 65 years or above & 15 & 6.7 & 4 & 3.1 & 11 & 11.6 \\
\hline
\end{tabular}


Table 3. Cont.

\begin{tabular}{|c|c|c|c|c|c|c|c|}
\hline \multirow{2}{*}{ Variable } & & \multicolumn{2}{|c|}{$\begin{array}{l}\text { Overall Visitors } \\
(n=223)\end{array}$} & \multicolumn{2}{|c|}{$\begin{array}{l}\text { Local Visitors } \\
(n=128)\end{array}$} & \multicolumn{2}{|c|}{$\begin{array}{l}\text { Nonlocal Visitors } \\
(n=95)\end{array}$} \\
\hline & & Number & $\begin{array}{l}\text { Percentage } \\
\text { (\%) }\end{array}$ & Number & $\begin{array}{l}\text { Percentage } \\
\text { (\%) }\end{array}$ & Number & $\begin{array}{l}\text { Percentage } \\
(\%)\end{array}$ \\
\hline \multirow{5}{*}{$\begin{array}{l}\text { Level of } \\
\text { education }\end{array}$} & Elementary school & 0 & 0.0 & 0 & 0.0 & 0 & 0.0 \\
\hline & Junior high school & 9 & 4.0 & 4 & 3.1 & 5 & 5.3 \\
\hline & $\begin{array}{l}\text { High school/vocational } \\
\text { school }\end{array}$ & 50 & 22.4 & 29 & 22.7 & 21 & 22.1 \\
\hline & $\begin{array}{l}\text { University/college for } \\
\text { professional training }\end{array}$ & 126 & 56.5 & 73 & 57.0 & 53 & 55.8 \\
\hline & $\begin{array}{l}\text { Graduate studies } \\
\text { and above }\end{array}$ & 38 & 17.0 & 22 & 17.2 & 16 & 16.8 \\
\hline \multirow{6}{*}{$\begin{array}{l}\text { Monthly } \\
\text { income }\end{array}$} & Below NT $\$ 20,000$ & 53 & 23.8 & 31 & 24.2 & 22 & 23.2 \\
\hline & NT $\$ 20,000-N T \$ 40,000$ & 66 & 29.6 & 44 & 34.4 & 22 & 23.2 \\
\hline & NT $\$ 40,000-N T \$ 60,000$ & 60 & 26.9 & 31 & 24.2 & 29 & 30.5 \\
\hline & NT $\$ 60,000-N T \$ 80,000$ & 28 & 12.6 & 16 & 12.5 & 12 & 12.6 \\
\hline & NT $\$ 80,000-N T \$ 100,000$ & 8 & 3.6 & 3 & 2.3 & 5 & 5.3 \\
\hline & Above NT $\$ 100,000$ & 8 & 3.6 & 3 & 2.3 & 5 & 5.3 \\
\hline \multirow{10}{*}{ Profession } & Student & 28 & 12.6 & 25 & 19.5 & 3 & 3.2 \\
\hline & $\begin{array}{l}\text { Military, government } \\
\text { employee, or teacher }\end{array}$ & 35 & 15.7 & 13 & 10.2 & 22 & 23.2 \\
\hline & Industrial sector & 29 & 13.0 & 18 & 14.1 & 11 & 11.6 \\
\hline & Commerce & 20 & 9.0 & 13 & 10.2 & 7 & 7.4 \\
\hline & Service industry & 39 & 17.5 & 28 & 21.9 & 11 & 11.6 \\
\hline & Freelance & 19 & 8.5 & 7 & 5.5 & 12 & 12.6 \\
\hline & $\begin{array}{l}\text { Agricultural, forestry, } \\
\text { fishery and husbandry }\end{array}$ & 3 & 1.3 & 1 & 0.8 & 2 & 2.1 \\
\hline & Unemployed & 3 & 1.3 & 1 & 0.8 & 2 & 2.1 \\
\hline & Retired & 28 & 12.6 & 10 & 7.8 & 18 & 18.9 \\
\hline & Other & 18 & 8.1 & 11 & 8.6 & 7 & 7.4 \\
\hline \multirow{2}{*}{$\begin{array}{l}\text { Place of } \\
\text { residence }\end{array}$} & Local & 128 & 57.4 & & & & \\
\hline & Nonlocal & 95 & 42.6 & & & & \\
\hline
\end{tabular}

Source: Compiled by this study. Note: The gray color represents the highest value.

\subsection{Visitors' Recreational Behavior}

The results of the visitors' recreational behavior are shown in Table 4. In terms of recreational demand, most people visited HNFRA just once in the previous year, accounting for $64.6 \%$ of the total, with the average annual number of visits being 1.71 (Figure 2). In terms of the average number of visits, the majority of respondents had visited only once, accounting for $69.1 \%$ of the total, as shown in Figure 3. Regarding the recreational demands of the local and nonlocal visitors, most of them visited only once, accounting for $51.2 \%$ of the local visitors and $83.2 \%$ of the nonlocal visitors. As for those who visited four times (or more), local people represented a higher percentage than the nonlocal visitors, with an approximate 10-fold difference. The average number of visits for the local visitors was 2.05 and the average number of visits for the nonlocal visitors was 1.25. As for substitute sites, most of the respondents visited HNFRA intentionally, accounting for $90.6 \%$ of the total. As for their length of stay, the majority of the visitors stayed for 2 days and 1 night, accounting for $31.4 \%$ of all the participants. The average length of stay was $16.49 \mathrm{~h}$. The length of stay for the majority of local visitors was 4 to $6 \mathrm{~h}$, accounting for $34.1 \%$ of the local visitors. The length of stay for the majority of nonlocal visitors was 2 days and 1 night, accounting for $49.5 \%$ of the nonlocal visitors. In terms of transportation, most visitors 
arrived by car, accounting for $75.3 \%$ of the total. Vehicles were also the main means of transport for the local and nonlocal visitors. Among the nonlocal visitors, tour buses also played a pertinent role, because the majority of nonlocal visitors usually arrive with organized tours. As for the travelling time, the overall average was $2.28 \mathrm{~h}$, with an average of $1.73 \mathrm{~h}$ for the local visitors and $3.01 \mathrm{~h}$ for the nonlocal visitors. As for the total number of people whom each respondent visited the site with, the overall average was 20.43 people, the average for the local visitors was 10.90 people, and the average of the nonlocal visitors was 33.28 people. In terms of the environmental rating, the average was 7.44 points (out of 10); thus, the visitors perceived the overall environmental quality of the site as relatively high.

Table 4. Frequency statistics analysis of the visitors' recreational behavior.

\begin{tabular}{|c|c|c|c|c|c|c|c|}
\hline \multirow[t]{2}{*}{ Variable } & & \multicolumn{2}{|c|}{$\begin{array}{l}\text { Overall Visitors } \\
(n=223)\end{array}$} & \multicolumn{2}{|c|}{$\begin{array}{l}\text { Local Visitors } \\
(n=128)\end{array}$} & \multicolumn{2}{|c|}{$\begin{array}{l}\text { Nonlocal Visitors } \\
(n=95)\end{array}$} \\
\hline & & Number & Percentage & Number & Percentage & Number & Percentage \\
\hline \multirow{4}{*}{$\begin{array}{l}\text { Recreational } \\
\text { demand }\end{array}$} & Number of visits (1) & 144 & 64.6 & 66 & 51.2 & 79 & 83.2 \\
\hline & Number of visits (2) & 32 & 14.3 & 21 & 16.3 & 11 & 11.6 \\
\hline & Number of visits (3) & 14 & 6.3 & 12 & 9.3 & 2 & 2.1 \\
\hline & $\begin{array}{l}\text { Number of visits (4 or } \\
\text { above) }\end{array}$ & 33 & 14.8 & 30 & 23.3 & 3 & 3.2 \\
\hline \multirow{2}{*}{ Substitute site } & Intentional visit & 202 & 90.6 & 116 & 89.9 & 87 & 91.6 \\
\hline & Fortuitous visit & 21 & 9.4 & 13 & 10.1 & 8 & 8.4 \\
\hline \multirow{7}{*}{ Length of stay } & Below $2 \mathrm{~h}$ & 11 & 4.9 & 4 & 3.1 & 7 & 7.4 \\
\hline & $2-4 \mathrm{~h}$ & 42 & 18.8 & 26 & 20.2 & 16 & 16.8 \\
\hline & $4-6 \mathrm{~h}$ & 60 & 26.9 & 44 & 34.1 & 17 & 17.9 \\
\hline & $6-8 \mathrm{~h}$ & 19 & 8.5 & 15 & 11.6 & 4 & 4.2 \\
\hline & 2 days, 1 night & 70 & 31.4 & 23 & 17.8 & 47 & 49.5 \\
\hline & 3 days, 2 nights & 4 & 1.8 & 1 & 0.8 & 3 & 3.2 \\
\hline & 4 days, 3 nights & 17 & 7.6 & 16 & 12.4 & 1 & 1.1 \\
\hline \multirow{5}{*}{$\begin{array}{l}\text { Means of } \\
\text { transportation }\end{array}$} & Motorcycle/scooter & 12 & 5.4 & 12 & 9.3 & 0 & 0.0 \\
\hline & Automobile & 168 & 75.3 & 105 & 82.2 & 63 & 66.3 \\
\hline & Walking, bicycle & 1 & 0.4 & 1 & 0.8 & 0 & 0.0 \\
\hline & Public transportation & 5 & 2.2 & 1 & 0.8 & 4 & 4.2 \\
\hline & Tour bus & 37 & 16.6 & 9 & 7.0 & 28 & 29.5 \\
\hline
\end{tabular}

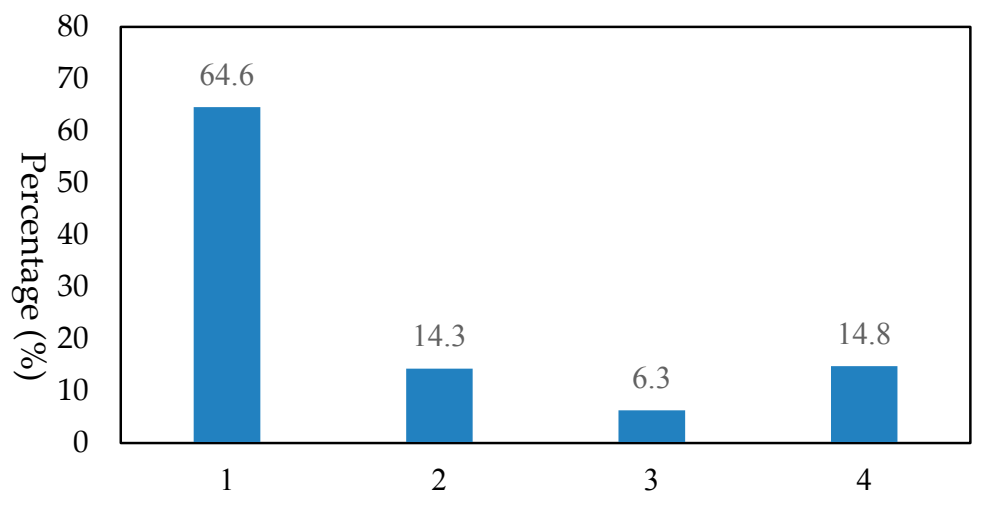

Number of visits

Figure 2. Number of visits to HNFRA over the last. 


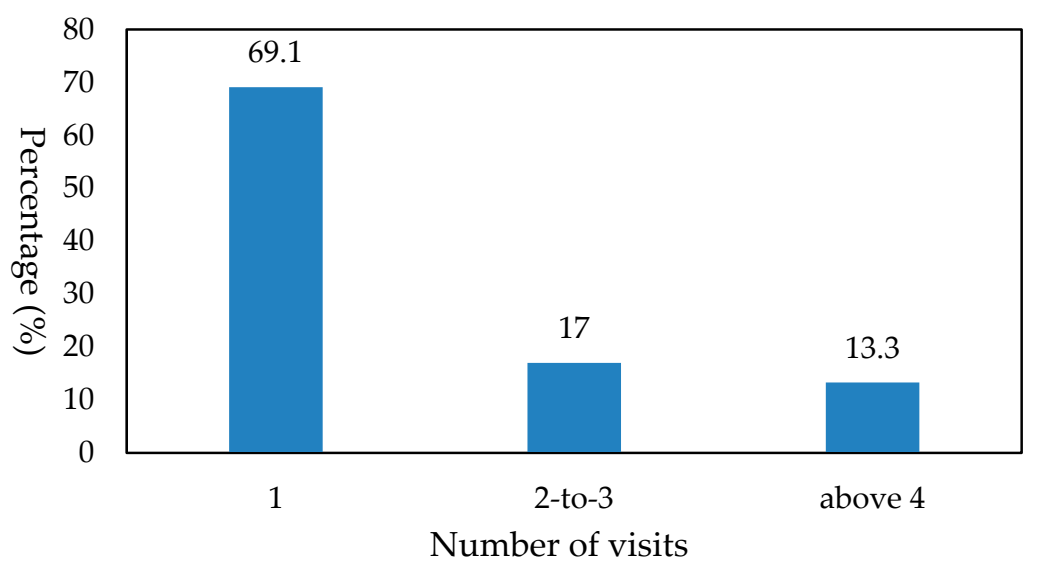

Figure 3. Average number of visits to HNFRA on a yearly basis.

\subsection{Visitors' Preferences}

An analysis of the visitors' preferences revealed the recreational activities that they liked to engage in. As reported in Table 5, a majority of the visitors liked to walk and engage in "forest bathing," accounting for $24.2 \%$, followed by "enjoying the scenery," which accounted for $22.5 \%$, and "mountaineering" and "resting on a hammock," both accounting for $15.0 \%$. Few of the respondents engaged in "sports games" or "academic research." Thus, the main activities that the visitors liked to engage in when they visited HNFRA were, respectively, "forest bathing," "enjoying the scenery," "mountaineering," and "resting on a hammock."

Table 5. Frequency statistics analysis of the activities visitors liked to engage in.

\begin{tabular}{lllllllll}
\hline Item & $\begin{array}{l}\text { Enjoying } \\
\text { the Scenery }\end{array}$ & Mountaineering & $\begin{array}{l}\text { Academic } \\
\text { Research }\end{array}$ & $\begin{array}{l}\text { Playing } \\
\text { with the } \\
\text { Water }\end{array}$ & Picnicking & $\begin{array}{l}\text { Resting on a } \\
\text { Hammock }\end{array}$ & $\begin{array}{l}\text { Playing } \\
\text { Sports }\end{array}$ & $\begin{array}{l}\text { Forest } \\
\text { Bathing }\end{array}$ \\
\hline $\begin{array}{l}\text { Number } \\
\text { (percentage) }\end{array}$ & 153 & 102 & 14 & 74 & 60 & 102 & 10 \\
164 & $(22.5 \%)$ & $(15.0 \%)$ & $(2.1 \%)$ & $(10.9 \%)$ & $(8.8 \%)$ & $(15.0 \%)$ & $(1.5 \%)$ & $(24.2 \%)$ \\
\hline
\end{tabular}

Source: Compiled by this study. Note: The observation percentage was $305.9 \%$. This item was a multiple-choice question; thus the sum exceeded $100 \%$. The gray color represents the highest value.

\subsection{Visitors' Willingness to Revisit and Environment Assessment}

Table 6 shows the results regarding visitors' willingness to revisit and environment assessment. The highest mean value for "willing to revisit HNFRA" was 4.28, followed by "willing to recommend HNFRA to other people" with a mean value of 4.25. The mean value for "willing to revisit HNFRA" was the highest; a possible reason for this might be that there are many beautiful landscapes, which cannot be all viewed in just one visit. The high willingness to return may also be because there are special activities worth seeing at certain times of the year, such as the firefly season and the cherry blossom season. Moreover, HNFRA also features special recreational activities, such as resting on a hammock, river wading, and picnicking on the grass. These activities influence tourists to return to the site. As for the environment assessment, the average score was 7.44 points, which indicated that the visitors generally had a positive perception of the environment. 
Table 6. Frequency statistics analysis of the visitors' willingness to revisit and the environment assessment.

\begin{tabular}{llllllll}
\hline Variables & & $\begin{array}{l}\text { Absolutely } \\
\text { Not Willing }\end{array}$ & $\begin{array}{l}\text { Not } \\
\text { Willing }\end{array}$ & Maybe & Willing & $\begin{array}{l}\text { Absolutely } \\
\text { Willing }\end{array}$ & Mean \\
\hline \multirow{3}{*}{$\begin{array}{l}\text { Willingness } \\
\text { to revisit }^{1}\end{array}$} & Willing to revisit & 0 & 2 & 20 & 114 & 87 & 4.28 \\
& Willing to recommend & $(0.0 \%)$ & $(0.9 \%)$ & $(9.0 \%)$ & $(51.1 \%)$ & $(39.0 \%)$ & \\
& the site to other people & $(0.0 \%)$ & $(0.4 \%)$ & $(11.7 \%)$ & $(50.7 \%)$ & $(37.2 \%)$ & 4.25 \\
& HNFRA is one of your & 2 & 4 & 40 & 117 & 60 & 4.03 \\
\hline Environment $_{\text {assessment }}{ }^{2}$ & first priority scenic spots & $(0.9 \%)$ & $(1.8 \%)$ & $(17.9 \%)$ & $(52.5 \%)$ & $(26.9 \%)$ & \\
\hline
\end{tabular}

Source: Compiled by this study. Note: 1 . The content of the table "willingness to revisit" is expressed in numbers (percentage); we used the five-point Likert scale as a measurement method. 2. The environmental score was chosen in the range 1 (very poor) to the highest 10 (very good).

\subsection{Travel Cost Analysis}

As shown in Table 7, the average accommodation cost was NT\$446.24 per trip, the average transportation cost was NT $\$ 259.43$ per trip, the average time cost was NT $\$ 454.20$ per trip, and the average consumer expenditure was NT\$707.91 per trip. Therefore, the travel costs (accommodation cost + transportation cost + time cost + consumer expenses) were NT\$1946.38 per capita. The average consumer expenditure accounted for a maximum of $41.1 \%$ of the total travel costs, whereas the average transportation cost accounted for a minimum of $13.3 \%$ of the total travel costs.

Table 7. Travel cost analysis of visitors to HNFRA.

\begin{tabular}{lllllll}
\hline \multirow{2}{*}{ Variable Code } & \multicolumn{2}{l}{$\begin{array}{l}\text { Overall Visitors } \\
(\boldsymbol{n}=\mathbf{2 2 3})\end{array}$} & $\begin{array}{l}\text { Local Visitors } \\
(\boldsymbol{n}=\mathbf{1 2 8})\end{array}$ & \multicolumn{2}{l}{$\begin{array}{l}\text { Nonlocal Visitors } \\
(\boldsymbol{n}=\mathbf{9 5})\end{array}$} \\
\cline { 2 - 7 } & Mean & $\begin{array}{l}\text { Standard } \\
\text { Deviation }\end{array}$ & Mean & $\begin{array}{l}\text { Standard } \\
\text { Deviation }\end{array}$ & Mean & $\begin{array}{l}\text { Standard } \\
\text { Deviation }\end{array}$ \\
\hline A & 446.24 & 1014.27 & 369.41 & 1254.71 & 544.48 & 530.62 \\
MTC & 259.43 & 201.72 & 205.21 & 189.67 & 332.49 & 195.19 \\
TTC & 454.20 & 351.81 & 326.69 & 238.70 & 626.01 & 404.17 \\
OE & 800.67 & 707.49 & 717.11 & 665.34 & 913.25 & 749.49 \\
Travel costs (A + OE + TTC + MTC) & 1946.38 & 2773.94 & 1597.65 & 1697.46 & 2416.24 & 1248.69 \\
\hline
\end{tabular}

Source: Compiled by this study. Note: "A" represents the accommodation costs (NT\$), "MTC" the transportation costs (NT\$), "TTC" the time cost (NT\$), and "OE" the consumer expenditure (NT\$). The gray color represents the higher value.

Numerous studies have shown that different travel distances affect travel participation patterns and travel costs [30]. This study divided the visitors into two categories according to their "place of residence" (namely local and nonlocal visitors), and then explored the differences between the two groups. The nonlocal visitors had greater travel costs than the local visitors had; the average cost of accommodation was NT\$369.41 per trip for the local visitors and NT\$544.48 for the nonlocal visitors. According to Liston-Heyes and Heyes (1999) [31], many TCM studies that have focused on "round-trip on the same day" do not apply to tourists who are relatively far from recreational areas, because those visitors usually spend the night. Therefore, the accommodation costs of the nonlocal visitors who stayed at HNFRA were greater than those of the local visitors. In terms of average transportation costs, the local visitors spent NT\$205.21 per trip, whereas the nonlocal visitors spent NT\$332.49.

Because the distance travelled by the nonlocal visitors was greater than that travelled by the local visitors, the average transportation cost was higher for the nonlocal visitors. In terms of average time costs, the local visitors spent NT\$326.69 per trip, whereas the nonlocal visitors spent NT\$626.01 (the time cost was calculated using round-trip travel time and monthly income as the main variables). Note that the average travel time was longer for the nonlocal visitors than for the local visitors and that the monthly income of the local visitors was lower than that of the nonlocal visitors. A possible reason for 
this might be that the local visitors mainly comprised students. Moreover, accommodation costs, food costs, and length of stay have a direct positive correlation [32-34].

Table 7 shows that the nonlocal visitors tended to stay at the recreational site for 2 days and 1 night; thus, the average consumer expenditure was higher for the nonlocal visitors compared with the local visitors. For the travel costs (accommodation costs + transportation costs + time cost + consumer expenditures), the local visitors spent NT\$1597.65 per trip, whereas the nonlocal visitors spent NT\$2416.24. The travel costs for nonlocal visitors were higher than those for local visitor NT\$818.59. The travel costs for the nonlocal visitors were higher than those for the local visitors due to the influence of factors such as the length of stay, the distance between the place of residence and the recreational site, and monthly income.

An independent sample $t$ test was used to examine the impact of gender and place of residence on general travel costs, and a one-way analysis of variance was used to examine differences with age, level of education, monthly income, occupation status, and length of stay, and whether different variables had a significant effect on total travel costs.

\subsection{Recreational Demand}

This study used the ZTNB to estimate the visitors' recreational demand, which was the dependent variable, whereas socioeconomic background and recreational behavior were the independent variables. The results are shown in Table 8.

Table 8. Estimated results of the HNFRA recreational demand model.

\begin{tabular}{llll}
\hline Variables & Overall Visitors & Nonlocal Visitors & Local Visitors \\
\hline Ln (A+OE+TTC+MTC) & -0.024 & -0.190 & -0.002 \\
\hline $\begin{array}{l}\text { Place of residence (AREA) } \\
\quad \text { Local }\end{array}$ & $0.438^{* *}$ & - & - \\
$\quad$ Nonlocal & - & - & - \\
\hline $\begin{array}{l}\text { Gender (GENDER) } \\
\quad \text { Male }\end{array}$ & 0.039 & 0.085 & -0.002 \\
$\quad$ Female & - & - & - \\
\hline Age (AGE) & $0.010^{*}$ & 0.014 & 0.006 \\
\hline Level of education (EDU) & 0.125 & 0.186 & 0.135 \\
\hline Ln (INC) & -0.258 & -0.236 & -0.134 \\
\hline Length of stay (LOS) & 0.004 & -0.001 & $0.006^{*}$ \\
\hline Travelling time (TRATIME) & -0.046 & -0.048 & 0.020 \\
\hline Substitute sites (SUBSITE) & & & -0.055 \\
\hline Intentional trip & -0.028 & 0.189 & - \\
\hline Fortuitous trip & - & - & $-0.020 * *$ \\
\hline Number of people (NIP) & -0.002 & 0.000 & -0.013 \\
\hline Environmental rating (SAT) & 0.005 & -0.002 & 1.631 \\
\hline$\beta_{0}$ & 2.276 & 2.732 & 0.000 \\
\hline$\alpha$ coefficient value ${ }^{*}$ & 0.000 & 0.000 & 17.562 \\
\hline Likelihood ratio chi-square & $30.789 * *$ & 7.533 & -196.225 \\
\hline Log-likelihood value & -313.136 & -109.172 & $0.05, *<0.015^{*}$ \\
\hline
\end{tabular}

Source: Present study. Note: The recreational demand is the dependent variable. ${ }^{*} p<0.05,{ }^{* *} p<0.01 .{ }^{1}$ For $\alpha$ coefficient value $=0$, data are not over dispersed; for $\alpha$ coefficient value $>0$, some data are over dispersed, as shown in Table 9, for $\alpha$ coefficient value $=0$, no over dispersion is observed.

In terms of overall visitors, travel costs and recreational demands were negatively but not significantly affected. This result is consistent with Martinez-Espineira and Amoako-Tuffour (2008) [35] and Zhang et al. (2015) [14], and also meets the general demand curve principle, according to which every additional purchase of a unit results in diminishing marginal utility. That is, the higher the travel 
costs, the lower the recreational demand. Moreover, there was a significantly positive relationship between the place of residence and recreational demand, which was higher in the case of the local visitors compared with the nonlocal visitors. This result is consistent with that by Tu (2013) and Zhang et al. (2015) [14]. The reason for this might be that the distance between HNFRA and the place of residence affected the travel costs: The farther the distance was, the higher the transportation costs, the longer the transportation time, and the higher the time costs, thereby decreasing the visitors' motivation. Hence, the recreational demand from the nonlocal visitors was lower than that from the local visitors.

There was also a significantly positive relationship between age and recreational demand. This result is consistent with Oppermann (1995) [36], Zimmer et al. (1995) [37], Lohmann and Danielsson (2001) [38], Schröder and Widmann (2007) [39], and Chang (2015) [27]. The reason for this might be that for people who are retired or are about to retire, they are relatively flexible with their time and have more time to engage in recreational activities. Therefore, such people have relatively high recreational demands. As for the monthly income, there was a significantly negative relationship between the monthly income and recreational demand. This result is consistent with studies by Zhang et al. (2015) [14], Chang (2015) [27], Chen (1998) [8], and Liston-Heyes and Heyes (1999) [31]. However, the result is inconsistent with studies by Hsu (2008) [40], Tu (2013) [41], Lee et al. (2016) [42], and Chen et al. (2011) [43]. A possible reason for this inconsistency is that the studies were conducted at different study areas. For example, the research by Zhang et al. (2015) [14] focused on coastal beaches; the study area of the research by Chang (2015) [27] was Guandu Nature Park; Chen (1998) [8] studied the Qilan Forest Recreation Area; and Liston-Heyes and Heyes (1999) [31] investigated Dartmoor National Park. The results in the abovementioned studies found that people with a relatively high income tended to have relatively few recreational demands. However, Hsu (2008) 40] investigated the Museum of Natural Science in Taichung; and Tu (2013) [41] studied the National Science and Technology Museum in Kaohsiung and found that people with a relatively high income tended to have relatively high recreational demands. The presumed reason for this is that people with relatively high incomes choose faster and closer travel methods to reduce time costs [35,44]. Therefore, remote locations, such as the coast, the beach, forests, and natural parks may not be very attractive to high-income people living in urban areas. Conversely, if the research area is located in urban areas, these destinations seem to appeal to people with relatively high incomes. However, people with high incomes do not always have relatively few recreational demands for remote recreational areas, as demonstrated by Lee et al. (2016) [42] and Chen et al. (2011) [43]. Lee et al. (2016) [42] investigated Taroko National Park in Hualien County; and Chen et al. (2011) [43] investigated Xitou Nature Education Area in Tainan County. Both destinations are remote nonurban areas; however, the results of these studies differ from the results of this study. Unlike this study, in those two studies there was a significantly positive relationship between monthly income and recreational demands. The reason for this might be that those recreational areas are more popular than HNFRA.

As for the patterns of the nonlocal visitors and local visitors, the findings indicated that the patterns of the nonlocal visitors were not significant. As for the patterns of the local visitors, there was a significantly positive relationship between the length of stay and the recreational demand. This result differs from the findings of Loomis et al. (2000) [45], Huang and Chen (2011) [46], and Tu (2013) [41], but is consistent with Liao (2003) [47]. The longer the stay, the higher the recreational demand. The significantly negative effect of the number of people whom the visitors travelled with is consistent with Zhang et al. (2015) [14]. Most of the local visitors travelled by themselves; few travelled with a group. Therefore, the higher the number of people the visitors travelled with, the lower their recreational demand was.

\subsection{Recreational Value}

To estimate the recreational value, the consumer surplus theory is often used as an assessment method for measuring the maximum net benefit of visitors using recreational areas, represented as the 
difference between the price that consumers are willing to pay and the price that they actually pay [14]. As for the recreational value of HNFRA, this study used ZTNB to analyze the recreational demands. The coefficients derived from the above were brought into the demand model. Three kinds of demand functions can be obtained, which are, respectively, the entire group of visitors ( $\mathrm{E}(\mathrm{y} \mid \mathrm{x})$ Entires), nonlocal visitors ( $\mathrm{E}(\mathrm{y} \mid \mathrm{x})$ Visitors), and local visitors ( $\mathrm{E}(\mathrm{y} \mid \mathrm{x})$ Locals), as shown below:

$$
\begin{aligned}
& E(y \mid x)_{\text {Entries }}=\exp (-0.0000142 \cdot \mathrm{TC}+0.229) \\
& E(y \mid x)_{\text {Vistores }}=\exp (-0.0000537 \cdot \mathrm{TC}+0.333) \\
& E(y \mid x)_{\text {Locals }}=\exp (-0.0000060 \cdot \mathrm{TC}+0.701)
\end{aligned}
$$

where TC represents the travel costs, including A + OE + TTC + MTC as aforementioned. We then use the consumer surplus theory to conduct the evaluation. Assume that the average travel cost of the current period in all the samples is used as the upper limit of recreational costs, and the travel cost when the visitors' demand is zero is used as the lower limit. The recreational value (NT\$/person/year) as the entire group of visitors to HNFRA (CSEntires), nonlocal visitors (CSVisitors), and local visitors (CSLocals) can be derived by

$$
\begin{aligned}
C S_{\text {Entires }} & =\int_{e^{0.229}}^{1946} e^{-0.0000142(\mathrm{TC})+0.229} d(\mathrm{TC})=3237(\mathrm{NT} \$ / \text { person } / \text { year }) \\
C S_{\text {Visitors }} & =\int_{e^{0.333}}^{1946} e^{-0.0000537(\mathrm{TC})+0.333} d(\mathrm{TC})=3160(\mathrm{NT} \$ / \text { person } / \text { year }) \\
C S_{\text {Locals }} & =\int_{e^{0.701}}^{1946} e^{-0.00006(\mathrm{TC})+0.701} d(\mathrm{TC})=3201(\mathrm{NT} \$ / \text { person } / \text { year })
\end{aligned}
$$

The results are shown in Table 9. Regarding the entire group of visitors, the recreational value for each visitor to HNFRA was NT\$3237 annually (95\% confidence interval [CI]: NT\$2970-NT\$3523). Regarding nonlocal visitors, the recreational value for each visitor to HNFRA was NT\$3160 annually (95\% CI: NT\$2882-NT\$3514). As for the local visitors, the recreational value for each visitor at HNFRA was NT\$3201 annually (95\% CI: NT\$2889-NT\$3545). We then obtained the total recreational value for that year, which was NT\$347,270,560, by considering the recreational value of each person per trip and the total number of visitors to HNFRA in 2016, which was 182,390. As for the nonlocal visitors, the annual recreational value of HNFRA was NT\$461,081,920. Regarding the local visitors, the annual recreational value for HNFRA was NT $\$ 284,710,790$. The annual total recreational value of HNFRA per capita was higher for the local visitors compared with the nonlocal visitors, whereas the annual total recreational value for HNFRA was higher for the nonlocal visitors compared with the local visitors.

Table 9. Analysis of the recreational value.

\begin{tabular}{llll}
\hline & $\begin{array}{l}\text { Overall Visitors } \\
(\boldsymbol{n}=\mathbf{2 2 3})\end{array}$ & $\begin{array}{l}\text { Nonlocal Visitors } \\
(\boldsymbol{n}=\mathbf{9 5})\end{array}$ & $\begin{array}{l}\text { Local Visitors } \\
(\boldsymbol{n}=\mathbf{1 2 8})\end{array}$ \\
\hline Annual recreational demands per capita (times) & 1.70 & 1.25 & 2.05 \\
95\% confidence interval (CI) upper limit & 1.85 & 1.39 & 2.27 \\
$95 \%$ confidence interval (CI) lower limit & 1.56 & 1.14 & 1.85 \\
\hline Recreational value per capita per time (NT\$) & 1904 & 2528 & 1561 \\
\hline Annual recreational value per capita (NT\$) & 3237 & 3160 & 3201 \\
95\% confidence interval (CI) upper limit & 3523 & 3514 & 3545 \\
$95 \%$ confidence interval (CI) lower limit & 2970 & 2882 & 2889 \\
\hline Annual total recreational value (NT\$) & $347,270,560$ & $461,081,920$ & $284,710,790$ \\
\hline Source: Compiled by this study. Note: “Recreational value per capita per time" means the recreational value per \\
capita per time/annual number of visits per capita. “Annual total recreational value" means the recreational value \\
per capita per time $\times$ the total number of visitors in 2016 (182,390 visitors).
\end{tabular}




\section{Conclusions and Recommendations}

\subsection{Conclusions}

The purpose of this study was to construct an assessment model for the recreational value and the total recreational value of HNFRA using the TCM; to explore the differences and correlations between the characteristics of visitors' socioeconomic backgrounds and their recreational behaviors, along with their demands and travel costs; and to classify visitors into two categories (local visitors and nonlocal visitors) based on the distance between their places of residence and the HNFRA.

The results revealed that the recreational value of the HNFRA was NT\$3237 (per person a year) for all the visitors. As for nonlocal visitors, the recreational value was NT\$3160 (per person a year). The recreational value for the local visitors was NT\$3201 (per person a year). By taking the visitor count into consideration, the annual recreational value was estimated to be NT\$347,270,560. According to the regression analysis of visitors' socioeconomic backgrounds and recreational demands, there was a significantly positive relationship between place of residence, age, the length of stay, and the recreational demand; but there was a significantly negative relationship between visitors' monthly income and recreational demands. The contribution of this study is to enhance the management of the HFRA to (1) improve quality of recreation in Taiwan, (2) enhance recreational activities for visitors, and (3) develop tourism and increase consumer willingness and recreational demand.

\subsection{Recommendations}

Suggestions have been made in the following:

(1) It is suggested that the relevant management of HNFRA improve the quality of the accommodation and promote incentives to stay during nonpeak seasons to increase the number of visitors.

According to the results of this study, the recreational demand of the nonlocal visitors was relatively low. Moreover, the findings revealed that the nonlocal visitors tended to stay at the site for 2 days and 1 night, indicating their motivation for visiting HNFRA was low. Therefore, to increase the recreational demand of nonlocal visitors, it is suggested that the relevant management of HNFRA improve the quality of the accommodation and offer incentives for people to stay during the nonpeak seasons to reduce the travel costs of nonlocal visitors. This is essential for increasing the recreational demand of nonlocal visitors.

(2) It is suggested that the relevant management of HNFRA provide different types of recreational activities or facilities for different age groups, and improve the internal service quality to attract more visitors.

The findings of this study revealed that most of the visitors who were of retirement age or were young seemed to have relatively low recreational demands. Therefore, different age groups should experience different recreational activities, and the facilities and internal service quality should be improved to attract more visitors. Mobility is an issue for many people over a certain age. Therefore, the internal facilities and the services provided need to be improved. It is suggested that the relevant management of HNFRA increase barrier-free facilities as well as transit cars inside the park and provide a more comfortable environment and quality services for older people or those with reduced mobility. Regarding young visitors, HNFRA lacks enough recreational activities. Therefore, it is suggested that the management of HNFRA include some environmentally friendly recreational facilities, such as wood-related activities or stimulating mountain training grounds (such as steep slopes and single-plank bridges) to attract more young visitors. Moreover, HNFRA has a certain level of recognition due to its unique scenery, beautiful trails, hammocks, and other recreational activities. Therefore, HNFRA should continue to maintain and preserve its original and distinguishing features.

(3) It is suggested that the relevant management of HNFRA develop diverse tourism methods to increase consumer willingness and recreational demands. 
Providing diversified tourism methods has positive effects on increasing the recreational demands of visitors. Due to Taiwan's popular cycling activities in recent years, domestic cycling tours have become an alternative to the mainstream. Many travel agencies have introduced cycling routes and itineraries for bicycle enthusiasts to participate in. Therefore, it is suggested that the relevant management of HNFRA cooperate with travel agencies and plan cycling routes, so that HNFRA may become one of the main scenic spots for these cycling tours. Moreover, parent-child do-it-yourself activities can also be launched to use the natural resources owned by the park as materials to create ingenious works, such as cup-shell charms and craft sculptures, to promote the interaction between parents and children, as well as to increase visitors' willingness to consume and to visit. Raising the recreational demand and the willingness to consume has a direct impact on the recreational value. Enhancing the site's recreational value will be beneficial to the management of HNFRA.

\subsection{Limitations and Future Research}

Due to a lack of funding and limited capability of the authors of this study, the questionnaires could only be distributed in September and August during summer vacation. Therefore, we recommend that subsequent studies conduct a year-round survey to improve the accuracy of the findings and to obtain opinions from tourists during other seasons.

When calculating public transportation costs, the questionnaire should be designed more definitely in the future (e.g., where are the visitors from? Which transportation tools do they take?) Their complete transportation paths should be realized in detail, to more reflect the real costs.

Furthermore, because a lot of the respondents in this study were retirees, the monthly income data that they provided is questionable. For example, some respondents provided their income based on their monthly pension, and others stated that their income was zero because they did not work, without providing any information relating to a pension. Because this study respected the willingness of the respondents to include their personal data and did not interfere with their responses, this aspect is a research limitation when calculating the recreational value.

Author Contributions: The three co-authors together contributed to the completion of this article. W.-Y.L. was the first author analyzing the data, and drafted the manuscript; P.-Z.C. contributed to the investigation, data analysis, the results, and conclusion; and C.-M.H. acted as corresponding author on their behalf throughout the review, editing, and submission process.

Funding: This research received no external funding.

Conflicts of Interest: The authors declare no conflicts of interest.

\section{References}

1. Directorate General of Budget, Accounting and Statistics, Executive Yuan, Taiwan. Available online: https://www.moi.gov.tw/stat/english/ (accessed on 15 May 2017).

2. Zhang, H.Y. Evaluation of Recreation Value of Urban Forest Park Based on ITCM-Jingyuetan National Forest Park as an Example. Master's Thesis, Yanbian University, Yanji, China, 2016.

3. Tourism Bureau, Ministry of Transport and Communications, Taiwan. Available online: https://eng.taiwan. net.tw/ (accessed on 5 April 2017).

4. Huisun National Forest Recreation Area. Available online: http://huisun.nchu.edu.tw/ (accessed on 2 April 2017).

5. Ward, F.A.; Beal, D.J. Valuing Nature with Travel Cost Models: A Manual; Edward Elgar Publishing: Cheltenham, UK, 2000.

6. Liao, P.Y. Economic Evaluation of Recreation Benefits at Taiwan National Parks: Travel Demand System Frame. Master's Thesis, National Taiwan University, Taipei, Taiwan, 2006.

7. Rathnayake, R.M.W. Economic values for recreational planning at Horton Plains National Park, Sri Lanka. Tour. Geogr. 2016, 18, 213-232. [CrossRef]

8. Chen, L.K. Factors affecting recreation experiences and recreation values of forest recreational areas-a case study of Chi-Lan Forest Recreational Area. J. Ilan. Ins. Tech. 1998, 1, $27-37$. 
9. Zawacki, W.T.; Maarainko, A.; Bowder, J.M. A travel cost analysis of nonconsumptive wildlife-associated recreation in the United States. For. Sci. 2000, 46, 496-506.

10. Clawson, M. Methods of Measuring the Demand for and Value of Outdoor Recreation; Resources for the Future: Washington, DC, USA, 1959.

11. Clawson, M.; Knetsch, J.L. Economics of Outdoor Recreation; Johns Hopkins University Press: Baltimore, MD, USA, 1966.

12. Brown, W.G.; Nawas, F. Impact of aggregation on the estimation of outdoor recreation demand functions. American J. Agric. Econ. 1973, 55, 246-249. [CrossRef]

13. Gum, R.L.; Martin, W.E. Problems and solutions in estimating the demand for and value of rural outdoor recreation. Am. J. Agric. Econ. 1975, 11, 558-566. [CrossRef]

14. Zhang, F.; Wang, X.H.; Nunes, P.A.L.D.; Ma, C. The recreational value of Gold Coast Beaches, Australia: An application of the travel cost method. Ecosyst. Serv. 2015, 11, 106-114. [CrossRef]

15. Asafu-Adjaye, J. Environmental Economics for Non-Economists: Techniques and Policies for Sustainable Development, 2nd ed.; World Scientific Publishing: Singapore, 2005.

16. Bennett, J. Estimating the recreational use values of national parks. Tour. Econ. 1996, 2, 303-320. [CrossRef]

17. Rolfe, J.; Dyack, B. Valuing recreation in the Coorong Australia, with travel cost and contingent behavior models. Econ. Rec. 2011, 87, 282-293. [CrossRef]

18. Long, J. Regression Models for Categorical and Limited Dependent Variables; Advanced Quantitative Techniques in the Social Sciences, Book 7; SAGE Publications: Thousand Oaks, CA, USA, 1997.

19. Dobbs, I.M. Adjusting for sample selection bias in the individual travel cost method. J. Agric. Econ. 1993, 44, 335-342. [CrossRef]

20. Shaw, D. On-site samples' regression: Problems of non-negative integers, truncation, and endogenous stratification. J. Econ. 1988, 37, 211-223. [CrossRef]

21. McCullagh, P. Generalized linear models. European J. Oper. Res. 1984, 16, 285-292. [CrossRef]

22. Blackwell, B.D. The Economics of Coastal Foreshore and Beach Management: Use, Safe Bathing Facilities, Erosion and Conservation. Ph.D. Thesis, The University of Queensland, Brisbane, Australia, 2003.

23. Bowker, J.M.; Leeworthy, V.R. Accounting for ethnicity in recreation demand: A flexible count data approach. J. Leis. Res. 1998, 30, 64-78. [CrossRef]

24. Creel, M.D.; Loomis, J. Theoretical and empirical advantages of truncated count data estimators for analysis of deer hunting in California. Am. J. Agric. Econ. 1990, 72, 434-441. [CrossRef]

25. Bockstael, N.E.; McConnell, K.E.; Strand, I.E., Jr. A random utility model for sport fishing: Some preliminary results for Florida. Mar. Resour. Econ. 1989, 6, 245-260. [CrossRef]

26. McConnell, K.E. On-site time in the demand for recreation. Am. J. Agric. Econ. 1992, 74, 918-925. [CrossRef]

27. Chang, S.H. Recreational Benefits and Pricing Policy of Nature-Based Tourism: A Case Study of Guandu Nature Park. Master's Thesis, National Taipei University, Taipei, Taiwan, 2015.

28. Shi, D.Q.; Zhang, Y.J. Application of travel cost method in recreation value evaluation. J. Beijing For. Univ. 2010, 9, 69-74.

29. Ho, W.H. The Recreation Value of Rural Tourism in Sinpu. Master's Thesis, National Tsing Hua University, Hsinchu, Taiwan, 2013.

30. Yen, J.J. The development of tourism spatio-temporal framework. J. Out. Rec. Stu. 1993, 6, 31-53.

31. Liston-Heyes, C.; Heyes, A. Recreational benefits from the Dartmoor National Park. J. Environ. Manag. 1999, 55, 69-80. [CrossRef]

32. Gokovali, U.; Bahar, O.; Kozak, M. Determinants of length of stay: A parametric survival use of analysis. Tour. Manag. 2007, 28, 736-746. [CrossRef]

33. Kozak, M. Repeaters' behavior at two distinct destinations. Ann. Tour. Res. 2001, 28, 785-808. [CrossRef]

34. Wang, E.; Yu, Y.; Little, B.B.; Li, Z. Crop insurance premium design based on survival analysis model. Agric. Sci. Proc. 2010, 1, 67-75. [CrossRef]

35. Martinez-Espineira, R.; Amoako-Tuffour, J. Recreation demand analysis under truncation, overdispersion, and endogenous stratification: An application to Gros Morne National Park. J. Environ. Manag. 2008, 88, 1320-1332. [CrossRef]

36. Oppermann, M. Travel life cycle. Ann. Tour. Res. 1995, 22, 535-552. [CrossRef]

37. Zimmer, Z.; Brayley, R.E.; Searle, M.S. Whether to go and Where to go: Identification of important influences on seniors' decisions to travel. J. Travel Res. 1995, 33, 3-10. [CrossRef] 
38. Lohmann, M.; Danielsson, J. Predicting travel patterns of senior citizens: How the past may provide a key to the future. J. Vacat. Mark. 2001, 7, 357-366. [CrossRef]

39. Schröder, A.; Widmann, T. Demographic Change and Its Impact on the Travel Industry: Oldies-nothing but Goldies. In Trends and Issues in Global Tourism; Conrady, R., Buck, M., Eds.; Springer: Berlin/Heidlberg, Germany, 2007.

40. Hsu, C.Y. A Study on Recreation Benefits and Tourists' Evaluations for Museums-A Case of National Museum of Natural Science in Taiwan. Master's Thesis, National Chung Hsing University, Hsinchu, Taiwan, 2008.

41. Tu, C.S. The Economic Value of Museums and the Methods for Evaluation-A Case Study of National Science and Technology Museum in Taiwan. Master's Thesis, National Sun Yat-sen University, Kaohsiung, Taiwan, 2013.

42. Lee, C.H.; Chen, Y.T.; Hsieh, C.M.; Hsu, S.W. Economic assessment of tourism quality improvement programs for the Taroko National Park. Sports Exerc. Res. 2016, 18, 1-13.

43. Chen, Y.H.; Lee, C.H.; Chen, Y.H. Evaluation of economic benefits from visitor's ecotourism quality improvement in forest recreational area-a case of Chi-Tou Forest Recreational Area. Taiwanese Agric. Econ. Rev. 2011, 16, 1-40.

44. Lima, J.D.; Maia, M.L.; Lucas, K. Income vs. travel time: Why do the poorest and the richest travel fastest in Northeastern Brazil? Transp. Res. Proc. 2017, 25, 4285-4295. [CrossRef]

45. Loomis, J.B.; Yorizane, S.; Larson, D. Testing significance of multi-destination and multi-purpose trip effects in a travel cost method demand model for whale watching trips. Agric. Res. Econ. Rev. 2000, 29, 183-191. [CrossRef]

46. Huang, Y.L.; Chen, K.L. The effect of multiple destination trips on recreation benefits-an example of leisure agriculture in Yilan County, Taiwan. Taiwan. Agric. Econ. Rev. 2011, 16, 41-76.

47. Liao, H.H. Evaluating the Recreation Value of Yangmingshan National Park. Master's Thesis, Chinese Culture University, Taipei, Taiwan, 2003.

(C) 2019 by the authors. Licensee MDPI, Basel, Switzerland. This article is an open access article distributed under the terms and conditions of the Creative Commons Attribution (CC BY) license (http://creativecommons.org/licenses/by/4.0/). 